\title{
KİTİN İLE GÜÇLENDİRİLEN ELEKTROEĞRİLMİŞ NANOLİFLERİN AKTİF AMBALAJ MALZEMESİ OLARAK KULLANILABİLİRLİĞİNİN İNCELENMESİ
}

\author{
Mine Karabulut, Elif Atay, Aylin Altan* \\ Mersin Üniversitesi, Gıda Mühendisliği Bölümü, Mersin, Türkiye
}

Geliş / Received: 29.05.2019; Kabul / Accepted: 05.11.2019; Online bask1 / Published online: 27.11.2019

Karabulut, M., Atay, E., Altan, A. (2019). Kitin ile güçlendirilen elektroeğrilmiş nanoliflerin aktif ambalaj malzemesi olarak kullanılabilirliğinin incelenmesi. GIDA (2019) 44 (6) 1237-1252 doi: 10.15237/gida.GD19086.

Karabulut, M., Atay, E., Altan, A. (2019). Kitin ile güclendirilen elektroegrilmis nanoliflerin aktif ambalaj malzemesi olarak kullamlabilirliğinin incelenmesi. GIDA (2019) 44 (6) 1237-1252 doi: 10.15237/gida.GD19086.

\section{Öz}

Elektroeğirme, yüksek yüzey alanı/hacim oranına sahip farklı boyutlarda liflerin üretimi için yenilikçi bir yöntemdir. Bu çalışmanın amacı, nane uçucu yağı yüklü ve kitin lifleri/kitin mikro kristalleri ile güçlendirilmiş zein bazlı nanobiyokompozit malzemelerin elektroeğirme yöntemi ile üretilmesidir. Üretilen nanobiyokompozitlerin yüzey morfolojisi, mekanik özellikleri ve antimikrobiyal aktiviteleri belirlenmiştir. Polimer çözeltisine kitin liflerinin eklenmesi ile ortalama lif çapı artmıştır. Kitin mikro kristalleri içeren malzemelerin mekanik özelliklerinin, kitin lifi içeren malzemelere göre daha zayıf mekanik özelliklere sahip olduğu bulunmuştur. Kitin lifleri ve nane uçucu yağı içeren malzemeler test mikroorganizmaları üzerinde berrak zon oluşturmamıştır. Fakat kitin mikro kristalleri ile birlikte nane uçucu yaği içeren malzemeler, Staphylococcus aureus üzerinde Escherichia coli'den daha etkili olmuştur. Üretilen nanobiyokompozit malzemelerin potansiyel aktif ambalajlama sistemlerinin geliștirilmesinde kullanılabileceği düşünülmektedir. Anahtar kelimeler: Elektroeğirme, nanobiyokompozit, nane uçucu yağı, kitin lifleri, kitin mikro kristalleri.

\section{INVESTIGATION OF ELECTROSPUN NANOFIBERS STRENGTHENED WITH CHITIN AS ACTIVE PACKAGING MATERIAL}

\begin{abstract}
Electrospinning is an innovative method for the production of fibers with different sizes having a high surface area/volume ratio. The aim of this study was to produce zein based nanobiocomposite active packaging materials loaded with mint essential oil and strengthened by chitin fibers/chitin microcrystals using electrospinning. Surface morphologies, mechanical properties and antimicrobial activities of the produced nanobiocomposites were determined. The average fiber diameter increased with the addition of chitin fibers into polymer solution. It was found that the mechanical properties of materials containing chitin microcrystals were weaker than the materials containing chitin fibers. The composite materials containing chitin fibers and mint essential oil did not form a clear zone on the test microorganisms. However, materials containing chitin microcrystals with mint essential oil were more effective on Staphylococcus aureus than Escherichia coli. It is considered that nanobiocomposites produced can be used in the development of potential active packaging systems. Keywords: Electrospinning, nanobiocomposite, mint essential oil, chitin fibers, chitin microcrystals.
\end{abstract}

\footnotetext{
${ }^{*}$ Yazışmalardan sorumlu yazar/Corresponding author:

$\triangle$ aaltan@mersin.edu.tr, @ (+90) 3243610001 /17195

冝 $(+90) 3243610032$
} 


\section{GİRİ̧̧}

Son yillarda malzeme bilimi ve teknolojisinin gelişmesi, sürekli değişen tüketici taleplerine yanıt olarak gida ambalajlama sistemlerini de etkilemiştir. G1da maddelerinin üretiminden tüketimine kadar ürün koşullarının izlenmesi, gıda ambalajlama sistemlerinde nanoteknolojinin kullanımının gelişmesini sağlamıştır (Pereira de Abreu vd., 2012). Nanoteknoloji, malzemenin yapısını moleküler seviyede yeniden tasarlama ve birçok fonksiyonu bir arada bulunduran ambalaj malzemelerini üretme firsatı sunmaktadır. Gıda ambalajlanmasinda nanoteknoloji, nanokompozit ambalaj malzemelerinin üretilmesi ile akıllı ve aktif ambalaj malzemelerinin geliştirilmesinde kullanılmaktadır. Nanokompozit ambalaj malzemeleri, biyolojik olarak parçalanabilir olduklarından geleneksel petro-kimyasal türevli ambalajlara karşı umut verici bir alternatiftir. Akıllı paketleme sistemleri, nakliye ve depolama esnasında ambalajl gidanın durumunu izlemek ve hakkında bilgi sağlamaya yönelik karakterize edilmişlerdir. Aktif paketleme sistemleri ise gidaların raf ömrünü uzatmak için kullanılan, aynı zamanda tüketiciye taze ve güvenli şekilde yüksek kaliteli ürünler sunmayı hedefleyen, paketin geleneksel işlevinin ötesine geçtiği bir uygulamadır (Pereira de Abreu vd., 2012; Realini ve Marcos,
2014). Aktif paketleme uygulamaları, oksijen yakalayıcılar, nem düzenleyiciler, karbondioksit düzenleyiciler, etilen yakalayıcılar ve antimikrobiyal paketleme sistemlerinden oluşmaktadır (Vermeiren vd., 1999). Son zamanlarda, aktif ambalajlama için nanoliflerin kullanımına olan ilgi artmaktadır.

Gıda endüstrisi de dâhil olmak üzere birçok alanda kullanılan nanoliflerin üretimi için geliştirilen farklı yöntemler bulunmaktadır. Fakat bu yöntemler genellikle mekanik kuvvetleri temel alan, kurulumu zor ve pahalı sistemlerden oluşmaktadır. Elektroeğirme yönteminde ise diğer lif üretim yöntemlerinden farklı olarak elektrik alan kuvvetlerinin etkisiyle polimerlerden lif oluşumu sağlanmaktadır. Elektroeğirme, bir polimer çözeltisini yüksek elektrik alana maruz bırakarak ultra ince liflerin oluşumunda kullanılan fiziksel bir işlemdir (Torres-Giner, 2011). Birçok alanda kullanım potansiyeli olan elektroeğirme, nanometre çapında ve geniş bir yüzey alanına sahip lif üretmek için en etkili, avantajl1, uygulaması kolay, ucuz ve hızlı bir yöntemdir. Bu sistem genel olarak; bir yüksek gerilim güç kaynağ1, ayarlanabilir bir şırınga pompası, şırınga, iğne ve bir toplayıc1 plakadan meydana gelir. Elektroeğirme sistemi Şekil 1'de gösterilmiştir.

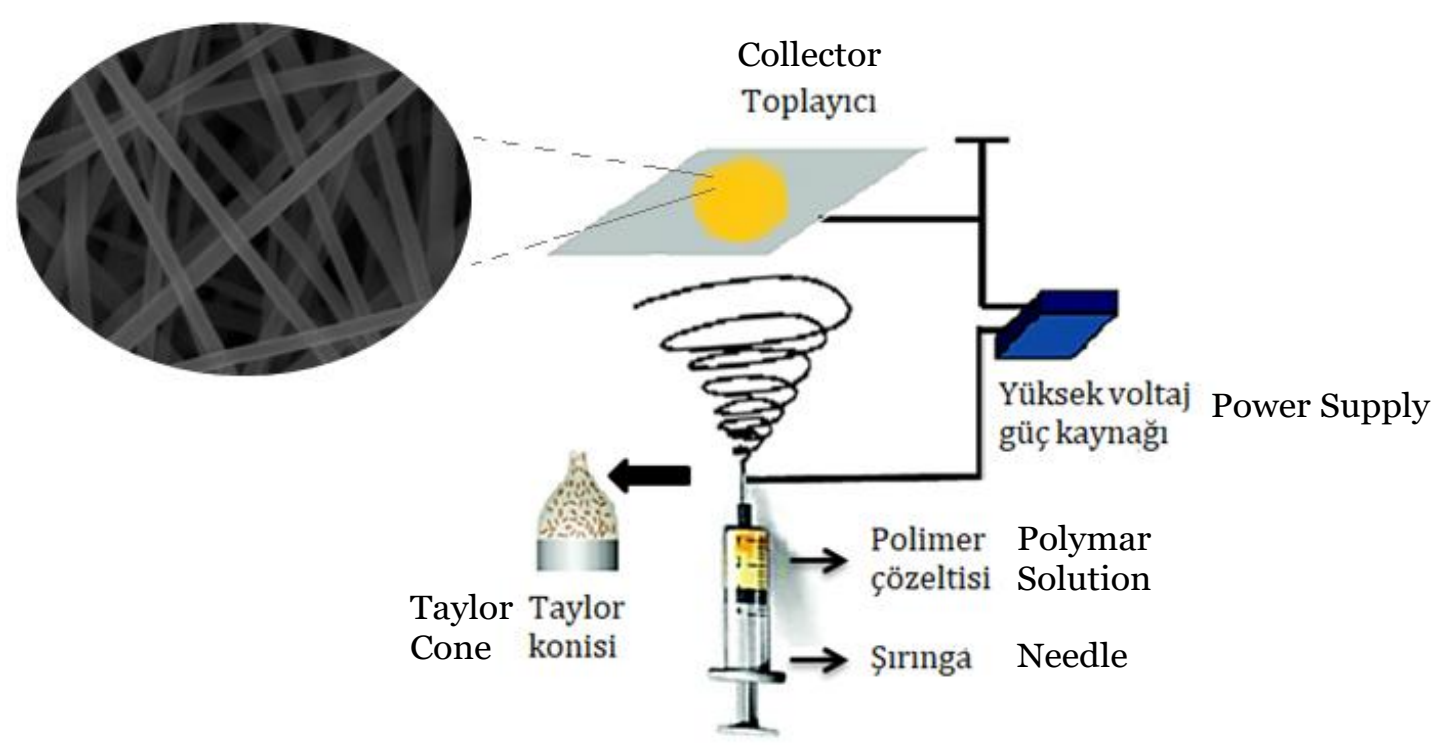

Şekil 1. Elektroeğirme düzeneği

Figure 1. Electrospinning system 
Elektroeğirme tekniği, gıda ambalajlarında kullanılan aktif ara katman üretimi için potansiyel oluşturan bir yöntemdir. Geleneksel döküm yöntemine kiyasla nano ve mikro lifler ultra-ince çaplarına bağlı olarak çok büyük bir yüzey/hacim oranina sahiptirler (Schmatz vd., 2019; TorresGiner, 2011). Nanolifler, elektroeğirme prosesi ile bir fazın diğeri içerisinde dağılmış halde bulunduğu üç boyutlu yapılar olan nanokompozitlere dönüşürülebilirler. Nanobiyokompozitler, biyolojik olarak parçalanabilen ve yenilenebilir doğal kaynaklardan elde edilen nanokompozitlerdir. Doğal biyopolimerlerden biri olan zein; misırdan elde edilen $\alpha_{-}, \Upsilon_{-}, \beta$ - ve $\delta$ - zeinin karışımı olan bir mısır proteinidir. Zein, film oluşturma özelliği, yüksek termal direnci ve iyi oksijen ve aroma bariyer özellikleri nedeniyle potansiyel ambalaj malzemelerinin geliştirilmesinde kullanılabilir. Ancak biyopolimerlerden elde edilen filmlerin, zayıf mekanik ve bariyer özelliklerinden dolayı ambalaj materyali olarak kullanımlarının sınırlı olduğu bildirilmektedir (Junkasem vd., 2006).

Nanokompozitlerin geliştirilmesinde, uçucu yağlar ve bazı dolgu malzemelerinin kullanımı oldukça yaygındır (Antunes vd., 2017; Wen vd., 2016). Fakat kullanilan dolgu malzemelerinin çoğu inorganiktir. İnorganik dolgu malzemelerinin yerine yenilenebilir kaynaklardan elde edilen kil kristalleri ve mikro kristaller de kullanılabilmektedir. $\mathrm{Bu}$ malzemeler, düşük maliyetli, kolay bulunabilir, toksik olmayan ve yenilenebilir olmalarının yanı sıra iyi mekanik ve bariyer özelliklere sahip olmalar1 sebebiyle inorganik malzemelere iyi bir alternatif olabilirler. Güçlendirici dolgu malzemesi olarak bilinen kil kristallerinin üretiminde kullanilan kitin, selülozdan sonra doğada en bol bulunan biyopolimerdir. Bu yapısal malzemenin büyük bir kısmı hayvanlarda, eklem bacaklıların dış iskeletlerinde (yengeçler, karidesler ve böcekler), bazı canlıların omurgalarında bulunmaktadır (Mincea vd., 2012). Doğal kaynaklardan elde edilen kitin ve türevleri yap1 birimleri üzerinde reaktif bir amino grubu bulundurduğundan kimyasal reaksiyonlar ile modifiye edilmesi selüloz kaynaklı malzemelerden daha kolaydır (Zeng vd., 2012). Bol miktarda kitin içeren gida sanayi atıkları, mikro kristallerinin üretimi için önemli bir kaynaktır. Güçlendirici dolgu malzemesi üretiminde öncelikle demineralizasyon, deproteinizasyon ve renk giderim işlemleri ile kitin saflaştırıldıktan sonra asit hidrolizi, santrifüj ve liyofilizasyon aşamaları gerçekleştirilerek mikro kristaller elde edilebilir (Paillet vd., 2001). Jin ve diğerleri (2017) tarafindan yapılan bir çalışmada, selüloz nano kristalleri (NCW) ile güçlendirilmiş lignin bazlı kompozit membranların üretiminde elektroeğirme yöntemi kullanılmışır. Elde edilen nanolifli yüzeylerin mekanik özellikleri incelenmiş ve $N C W$ 'lerin lignine eklenmesinin, saf lignine göre gerilme direncini arttırdığı belirlenmiştir. Bir diğer çalışmada ise zayıf mekanik özelliklere sahip olan poli( $\varepsilon$-kaprolakton) (PCL) biyopolimerinin güçlendirilmesi amacıyla alüminyum oksit $\left(\mathrm{Al}_{2} \mathrm{O}_{3}\right)$ kıl kristalleri kullanılmış ve elektroeğirilmiş membranlar üretilmiştir. Elde edilen sonuçlar, $\mathrm{Al}_{2} \mathrm{O}_{3}$ kristalleri içeren membranların saf PCL'ye göre daha iyi mekanik özelliklere sahip olduğunu göstermektedir (Dong vd., 2012).

Nanobiyokompozitlerin fonksiyonelleştirilerek aktif ambalajların elde edilmesinde uçucu yağlar çok sık kullanılmaktadır. Uçucu yağlar damıtma veya preslemeyle, bitkilerin yaprak, meyve, kabuk ve kök kısımlarından elde edilen oda sıcaklı̆ıında sıv1, genellikle renksiz veya açı sarı renkli kompleks bileşiklerdir. $\mathrm{Bu}$ bileşiklerin antimikrobiyal özellikleriyle gidalarda bozulma ve zehirlenmelere neden olan Listeria monocytogenes, Stapbylococcus spp., Bacillus spp., Campylobacter jejuni, Shigella spp., Escherichia coli gibi bakteriler, maya ve küfler üzerinde etkili olduğu bilinmektedir (Nostro vd., 2000; Sartoratto vd., 2004). Geçtiğimiz yllarda Tang ve diğerleri (2019) tarafindan yapilan bir çalışmada nane (PO) ve papatya uçucu yağı (CO) olmak üzere iki çeşit uçucu yağ içeren jelatin nanolifleri elektroeğirme yöntemi kullanılarak üretilmiştir. Nanoliflerin Escherichia coli ve Staphylococcus aureus'a karşı antibakteriyel aktivitesi incelendiğinde, her iki yağın kombinasyonu ile elde edilen nanolifli yüzeylerin optimum aktivite sağladığı ve geliştirilen jelatin/PO/CO nanoliflerinin, yenilenebilir ambalajlama için yenilikçi bir çözüm olabileceği belirtilmiştir. Antunes ve diğerleri (2017) yaptıkları bir çalışmada antimikrobiyal ajan 
olarak okaliptüs uçucu yağ1 (EEO) ve siklodekstrin (CD) kullanmış ve zein bazlı elektroeğirilmiş lifler üretmişlerdir. Üretilen antimikrobiyal kompozit membranların, gida koruyucusu olarak kullanımının umut verici olduğu belirtilmiştir. Antimikrobiyal özelliklerinin yanı sıra uçucu yağlar sahip oldukları fonksiyonel gruplar sebebiyle ambalaj materyalinin mekanik ve termal özelliklerinin iyileştirilmesi amacıyla da kullanılmaktadır. Ayrıca içerdikleri fonksiyonel gruplar sayesinde uçucu yağların, biyopolimer bazlı membranlara plastikleștirici etki kazandırdığı ve bu sebeple daha esnek yapilı materyallerin geliştirilebileceği belirlenmiştir (Wen vd., 2016).

Bu çalışma kapsamında elektroeğirme yöntemi kullanılarak nane uçucu yağı yüklü nanolifler elde edilmiştir. Nane uçucu yağı, Menthaspecies cinsi bitkilerden elde edilen ve gida sanayi, tıp, eczacilık ve kozmetikte kullanılan önemli bir bileşendir. Ayrıca nane uçucu yağının benzersiz antimikrobiyal, antifungal, antioksidan antiinflamatuar özelliklere de sahip olduğu bilinmektedir (Barrosa vd., 2015). Tüm bu etkilerinden dolayı uçucu yağlar gıda paketleme sistemlerinde biyopolimerlerin yapısına dâhil edilerek aktif ambalaj materyali üretiminde kullanılabilmektedirler.

$\mathrm{Bu}$ çalışmanın amacı, elektroeğirme yöntemi kullanılarak nane uçucu yağı yüklü ve güçlendirici dolgu malzemesi olarak kitin lifleri ve kitin mikro kristallerine sahip nanoliflerin aktif ambalaj sistemlerinde kullanım potansiyelinin araştırılmasıdır. Bu kapsamda saf zein, zein-nane uçucu yağı, zein-kitin lifleri/kitin mikro kristalleri ve zein-nane uçucu yağı-kitin lifleri/kitin mikro kristalleri içeren elekroeğrilmiş materyaller üretilmiştir. Üretilen materyallerin yüzey morfolojileri, kimyasal yapıları, mekanik ve antimikrobiyal özellikleri belirlenmiştir.

\section{MATERYAL VE YÖNTEM}

\section{Materyal}

Elektroeğrilmiş membran yapıların üretiminde kullanılan zein (Z3625) Sigma-Aldrich (St. Louis, MO, USA); glasiyal asetik asit ise Carlo Erba (Rodano, Italy) firmasından satın alınmıstır. Aktif materyal olarak kullanılan nane uçucu yağı (NUY),
Çakıroğlu firmasından (Çakıroğlu Uçucu Yağ San. Tic. Ltd. Şti., Mersin) temin edilmiştir. Kitin lifleri (KL) ve kitin mikro kristalleri (KMK) yerel bir pazardan temin edilen mavi yengeç atıklarının demineralizasyon, deproteinizasyon, asit hidrolizi, santrifüj ve liyofilizasyonu ile elde edilmiştir. Üretilen malzemelerin antimikrobiyal aktivitelerinin belirlenmesinde kullanilan Escherichia coli (ATCC 25922) ve Staphylococcus aureus (ATCC 25923) test mikroorganizma kültürleri, Mersin Üniversitesi Gıda Mühendisliği Mikrobiyoloji Laboratuvarından temin edilmiştir.

\section{Nane Uçucu Yağının Antimikrobiyal Aktivitesinin Belirlenmesi}

Nane uçucu yağının Escherichia coli (ATCC 25922) ve Staphylococcus aureus'a (ATCC 25923) karş1 antimikrobiyal aktivitesi agar disk difüzyon yöntemi kullanılarak belirlenmiştir. Kültürleri aktifleştirmek için Triptik Soy Broth (TSB) besiyeri, agar disk difüzyon yönteminde ise Mueller Hinton Agar (MHA) besiyeri kullanılmıştır. Stok kültürden öze ile alınan koloniler TSB besiyerine aşılanıp $37^{\circ} \mathrm{C}$ 'de 24 saat inkübasyona bırakılmışır. İnkübasyon süresinin sonunda kültür yoğunluğu spektrofotometre (Cary60UV-Vis, Agilent Technologies, Malezya) ile ölçülerek, McFarland 0.5 standardına göre $1 \times 10^{-8}$ olacak şekilde ayarlanmıştır. Yoğunluğu ayarlanan kültürden $0.1 \mathrm{~mL}$ alınıp MHA besiyerine ekim yapılmıştır. Uçucu yağın antimikrobiyal aktivite testi için kullanılacak diskler steril Whatman kağıtlarından $6 \mathrm{~mm}$ çapa sahip olacak şekilde elde edilmiştir. Nane uçucu yağ1 $20 \mu \mathrm{L}$ olacak şekilde steril disklere emdirilip petrilere yerleștirilmiştir. Petriler, $37^{\circ} \mathrm{C}$ 'de 24 saat inkübasyona birakilıp inkübasyon sonunda inhibisyon zonlar1 bir kumpas yardımıla ölçülmüştür (Tiryakioğlu, 2004). Antimikrobiyal aktivite testinde her örnek 3 paralel olarak çalışılmıştır.

\section{Kitin Lifleri ve Kitin Mikro Kristallerinin Hazırlanmas1}

Saf kitinden kitin lifleri (KL) ve kitin mikro kristalleri (KMK), iki farklı yöntem kullanılarak elde edilmiştir. Kitin pulcuklarının $3 \mathrm{~N} \mathrm{HCl}$ çözeltisi içerisindeki oranı $1 \mathrm{~g} / 30 \mathrm{~mL}$ olarak belirlenmiştir. Hazırlanan çözelti kaynamakta iken 
90 dakika boyunca güçlü bir şekilde karıştırılmıştır. Asit hidrolizi tamamlandıktan sonra süspansiyon santrifüj $(1390 \times \mathrm{x} g, 15 \mathrm{dk})$ edilmiştir. Santrifüj işlemi üç kez tekrarlanmıştır. Ardından süspansiyon tüm kalıntıların giderilmesi için $\mathrm{pH}=4$ olana kadar saf su ile diyaliz edilip liyofilizatörde (Cryodos 50, TELSTAR, Spain) kurutularak kitin lifleri elde edilmiştir (Zhang vd., 2004). Kitin mikro kristalleri ise kitin pulcuklarının $3 \mathrm{~N} \mathrm{HCl}$ çözeltisi içerisinde $104^{\circ} \mathrm{C}$ 'de 6 saat boyunca güçlü bir şekilde karıştırılarak hidroliz edilmesiyle hazırlanmıştır. Kitinin $\mathrm{HCl}$ çözeltisi içerisindeki oranı kitin lifleri üretimde olduğu gibi $1 \mathrm{~g} / 30 \mathrm{~mL}$ olarak belirlenmiştir. Asit hidrolizinden sonra elde edilen süspansiyon hemen saf su ile seyreltilip santrifüj (10397 x g, $15 \mathrm{dk}$ ) edilerek kitinin katı kısmının ayrılması sağlanmıştır. Santrifüj işlemi üç kez tekrarlanmıştır. Daha sonra süspansiyon içerisindeki hidroklorik asit kalıntısının giderilmesi için süspansiyon oda sıcaklığında saf su içerisinde $\mathrm{pH}=6$ olana kadar diyaliz edilmiştir. Süspansiyon 5 dakika ultrasonik cihazı (Kudos, SK1200H, China) ile homojen hale getirildikten sonra dondurarak kurutma yöntemiyle liyofilizatörde kurutulmuştur (Paillet vd., 2001).

\section{Deney Tasarımı}

Elektroeğirme prosesinde kullanılan zein çözeltisi, NUY, KL ve KMK konsantrasyonlar1 sirasiyla \%36 (a/h), \%13.4 (a/a) ve \%5 (a/a) olarak belirlenmiştir. Saf zein, zein-NUY, zein-KL/zeinKMK ve zein-KL-NUY/zein-KMK-NUY içeren çözeltiler elektroeğirme cihazında proses edilmiştir. Deney tasarımı detaylı olarak Çizelge 1'de verilmiştir.

Çizelge 1. Deney tasarımı

Table 1. Experimental design

\begin{tabular}{lcccc}
\hline $\begin{array}{l}\text { Deney } \\
\text { Run }\end{array}$ & $\begin{array}{c}\text { Zein çözeltisi } \\
\text { Zein solution }\end{array}$ & NUY & KL & KMK \\
\hline 1 & + & MEO & CF & $C M$ \\
2 & + & & & \\
3 & + & + & + & \\
4 & + & + & + & + \\
5 & + & & & + \\
6 & + & + & & \\
\hline
\end{tabular}

NUY:Nane uçucu yağı; KL:Kitin lifleri; KMK:Kitin mikro kristalleri; MEO:Mint essential oil; CF:Chitin fibers; CM:Chitin microcrystals.

\section{Çözeltilerin Hazırlanması}

Öncelikle saf zein çözeltisi $(\% 36, a / h)$ asetik asit içerisinde hazırlanmıştır. Elektroeğirme prosesinde kullanılan zein çözeltisine, zein ağırllğı üzerinden $\% 13.4 \quad(\mathrm{a} / \mathrm{a})$ oraninda NUY eklenmiştir. Deney tasarımına göre (Çizelge 1) nane uçucu yağ1 içeren zein çözeltisine, zein ağırlı̆ğ üzerinden $\% 5(\mathrm{a} / \mathrm{a})$ oranında KL ya da KMK ilave edilmiştir. Saf zein, zein-NUY, zeinKL, zein-KL-NUY; paralelinde saf zein, zeinNUY, zein-KMK ve zein-KMK-NUY içeren çözeltiler hazırlanmıştır.

\section{Yöntem}

\section{Elektroeğirme Yöntemi}

Elektroeğirme işlemi, Çizelge 1'de verilen deney tasarımına göre hazırlanan çözeltiler kullanılarak dikey çalışma prensibine göre tasarlanmış olan elektroeğirme cihazı (NE 100, Inovenso, Türkiye) ile gerçekleştirilmiştir. Elektroeğirme cihazı şırınga pompası (NE-300, New EraPump Systems Inc., USA), toplayıcı ve güç kaynağından oluşmaktadır. Uygulanan voltaj $25 \mathrm{kV}$, akış hızı 1 $\mathrm{mL} / \mathrm{sa}$ ve besleme ünitesi ile toplayıcı arasındaki mesafe ise $13.5 \mathrm{~cm}$ olarak sabit tutulmuştur. Üretilen elektroeğrilmiş membran yapilar alüminyum folyo üzerine toplanmıştır. Elektroeğirme işlemi oda koşullarında gerçekleştirilmiştir.

\section{Alan Emisyonlu Taramalı Elektron Mikroskobu (FE-SEM)}

Elektroeğirme tekniği ile üretilen nanolifli yüzeylerin morfolojisinin incelenmesi ve nanolif 
çaplarının tespit edilmesi için taramalı elektron mikroskobu (FE-SEM) (Supra 55, Zeiss, Germany) kullanılmıstır. Alınan her bir görüntüde 100 farklı ölçüm yapılarak ortalama çap bulunmuştur.

\section{Fourier Dönüşümlü Kız1lötesi \\ Spektrofotometre Analizi (FTIR)}

Nane uçucu yağının kitin mikro kristalleri ile güçlendirilmiş zein biyopolimerlerine eklenmesiyle elde edilen elektroeğirilmiş malzemelerde zein-uçucu yağ ve kitin mikro kristalleri arasında meydana gelen etkileşimler FTIR spektrofotometresi (FTIR/FIR/NIR SpectrometerFrontier, ATR, Perkin Elmer, UK) kullanılarak belirlenmiştir. Örneklerin FTIR spektrumları 4000-400 $\mathrm{cm}^{-1}$ aralığında $4 \mathrm{~cm}^{-1}$ spektral çözünürlüğü ile elde edilmiştir.

\section{Mekanik Özelliklerin Belirlenmesi}

Kitin lifleri/kitin mikro kristalleri ile güçlendirilmiş zein/nane uçucu yağ1 nanobiyokompozitlerinin mekanik özellikleri TA.XT2i Tekstür Analiz cihazı (Stable Micro Systems, Surrey, England) ile belirlenmiştir. Elektroeğirme yöntemi ile üretilen yapıların uzunluğu $5 \mathrm{~cm}$, genişlikleri ise $1.5 \mathrm{~cm}$ olacak şekilde kalıp kullanılarak kesilmiştir. Örneklerin kalınlıkları rastgele üç noktada dijital mikrometre (Mitutoyo, Japan) ile ölçülmüştür. Kesilen örnekler mandal şeklindeki A/TG probunun arasına yerleştirilerek $0.5 \mathrm{~mm} / \mathrm{s}$ test hızı uygulanarak kopma anında örneğe uygulanan maksimum kuvvet ve kopma anındaki uzama miktarı ölçülmüştür (Şekil 2). Gerilme direnci nanoliflerin yüzey alanları esas alınarak hesaplanıp $\mathrm{MPa}$ cinsinden ifade edilmiştir. Uzama miktarı $(\%)$ ise örneğin kopma anındaki yüzde uzama miktarı olarak tanımlanmıștır (Zivanovic vd., 2007). Her bir örnek için en az üç paralel ölçüm yapılmışır.

Kitin Lifleri/Kitin Mikro Kristalleri ile Güçlendirilmiş Zein/Nane Uçucu Yağ1 Nanobiyokompozit Yapıların Antimikrobiyal Aktivitenin Belirlenmesi

Disk şeklinde ve $6 \mathrm{~mm}$ çapında kesilmiş olan numuneler ekim yapılmış MHA besiyeri plağı üzerine yerleştirilerek $37^{\circ} \mathrm{C}$ de 24 saat inkübasyona bırakılmıştır. İnkübasyondan sonra inhibisyonun olduğu berrak zonun çap1 ölçülmüştür (Kara vd., 2016). Her bir örnek için üç paralel ölçüm yapılmıştır.

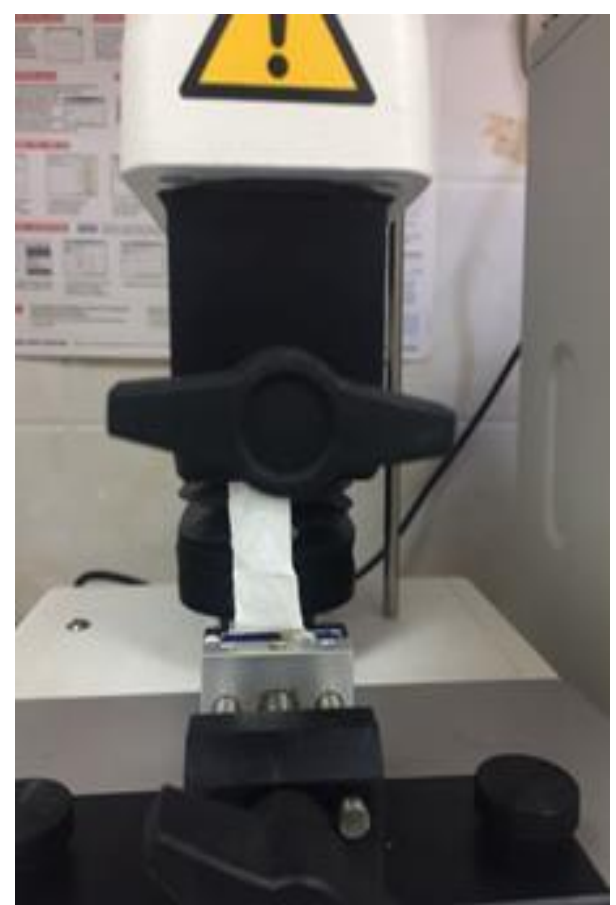

Şekil 2. Mekanik özelliklerin belirlenmesinde kullanılan tekstür analiz probu

Figure 2. Texture analysis probe used for the determination of mechanical properties

\section{SONUÇ VE TARTIŞMA}

\section{Morfolojik Analiz}

Nanobiyokompozit yapılı nanoliflerin düzgün bir çap dağılımı göstermesi ve boncuklu yapıların oluşmaması, elde edilen lifli yüzeylerin mekanik ve bariyer özellikleri ile aktif bileşenin salımı açısından önemlidir. Zein proteininden elde edilen yapılara kitin lifleri ile kitin mikro kristalleri ilave edilmiş ve bunların nanobiyokompozit yapılarının morfolojik özellikleri üzerine etkisi incelenmiştir. Kitin lifleri ve kitin mikro kristallerinin morfolojisi Şekil 3’te verilmiştir.

Üretilen nanobiyokompozit yapılı liflerin FESEM görüntüleri ve lif çaplarının dağılımı Şekil 4 ve Şekil 5'te gösterilmiştir. Hem kitin lifleri hem de kitin mikro kristallerinden elde edilen nanobiyokompozit yapıların morfolojileri düzgün ve homojen dağılmıştır. Histogram grafiklerine 
bakıldığında lif çaplarının çoğunluğunun ortalama $200 \mathrm{~nm}$ civarında yoğunlaştı̆̆1 ve düzenli bir dağılım gösterdiği görülmektedir. Üretilen liflerin ortalama çapları 79 ile $440 \mathrm{~nm}$ aralığında değişmektedir. Saf zein çözeltisi ve bu çözeltiye nane uçucu yağının eklenmesiyle elde edilen nanoliflerin ortalama çapları arasinda belirgin bir farkll1ık görülmemiştir ( $p>0.05)$. Bununla beraber kitin mikro kristallerinden elde edilen nanobiyokompozit yapıların lif çaplarının, kitin liflerinden elde edilen nanobiyokompozit yapıların lif çaplarına göre azalma gösterdiği belirlenmiştir. Ancak bu azalma istatistiksel olarak anlamlı $(p>0.05)$ bulunmamıștır. Bununla birlikte lif çaplarındaki azalmanın kitin mikro kristallerinin iyonik iletkenliklerine bağlı olduğu düşünülmektedir. Kitin mikro kristalleri çözücü içerisinde dağıtıldığında yüksek iyonik iletkenliğe yol açan amino grupları ortaya çıkar ve elektroeğirme işlemi sırasında polimer jetinin yük yoğunluğunu artırır. $\mathrm{Bu}$ nedenle, kitin mikro kristallerinin kitin liflerine kıyasla daha küçük çaplı liflerin üretimine sebep olduğu ancak mikro kristallerin miktarı artırıldığında ortalama lif çapının artırılabileceği düşünülmektedir (Wen vd., 2017). Benzer bir çalş̧mada poli(L-laktik asit) (PLLA) ve belirli oranlarda eklenen kitin k1 kristallerinden elektroeğirme yöntemi ile elde edilen nanolifli yüzeylerin lif çapı dağılımı incelenmiştir. Elde edilen sonuçlara göre PLLA ve kitin kıl kristalleri içeren nanoliflerin, düzgün ve homojen lif çap1 dağılımına sahip olduğu gözlenmiştir. $\mathrm{Bu}$ yapılar saf PLLA nanolifli yüzeyler ile karşılaştırıldığında, $\% 2.5$ ve $\% 5$ oranında kitin kıl kristalleri içeren nanobiyokompozitlerin lif morfolojisinde anlamlı bir farklılı̆̆ın olmadığı, ancak k1l kristalleri içeriği \%10 iken lif çaplarının arttığ1 görülmüştür (Liu vd., 2016).
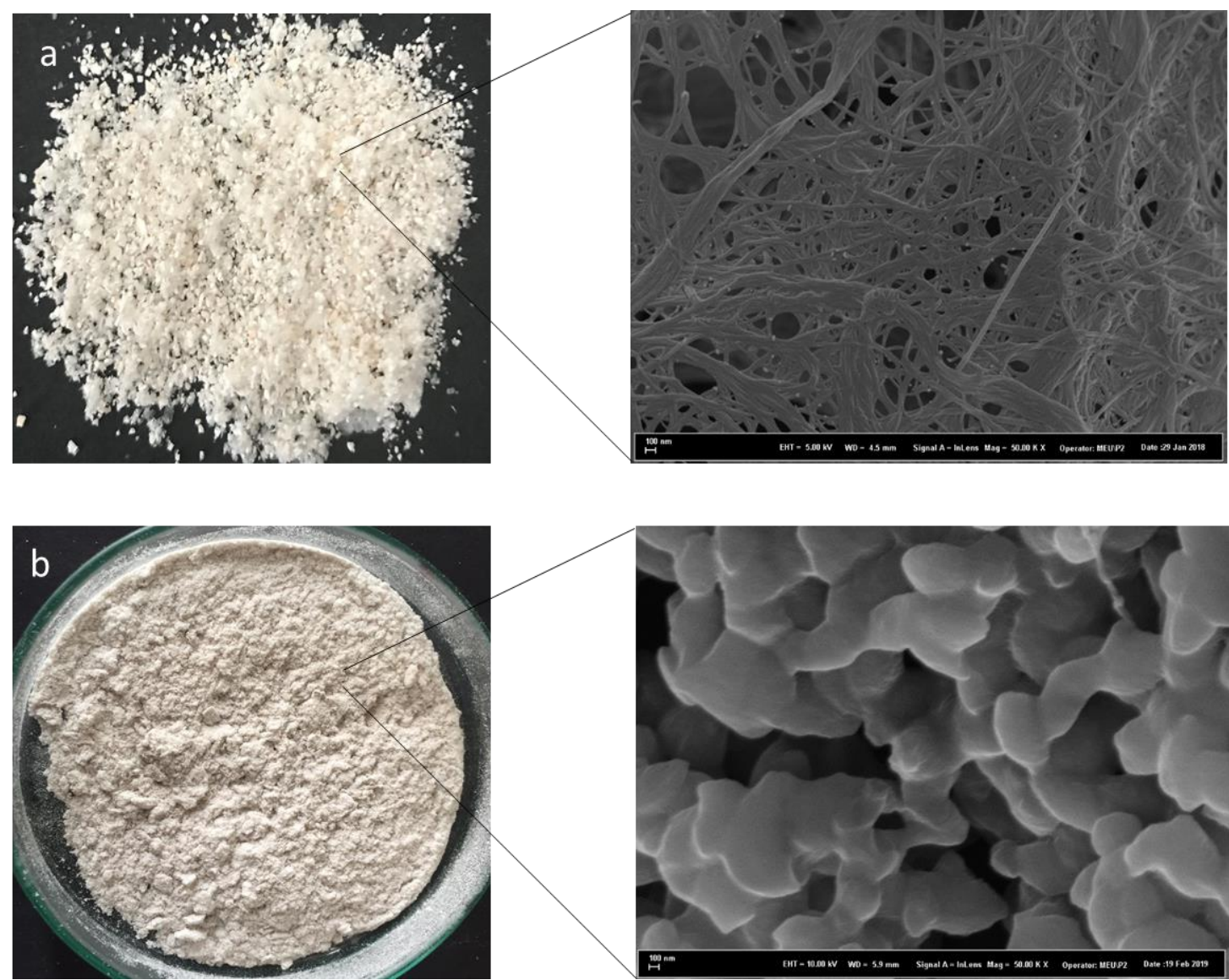

Şekil 3. Kitin lifleri (KL), mikro kristalleri (KMK) ve FE-SEM görüntüleri a) KL, b) KMK Figure 3. Chitin fibers (CF), microcrystals (CMC) and FE-SEM images a) $C F$, b) $C M C$ 

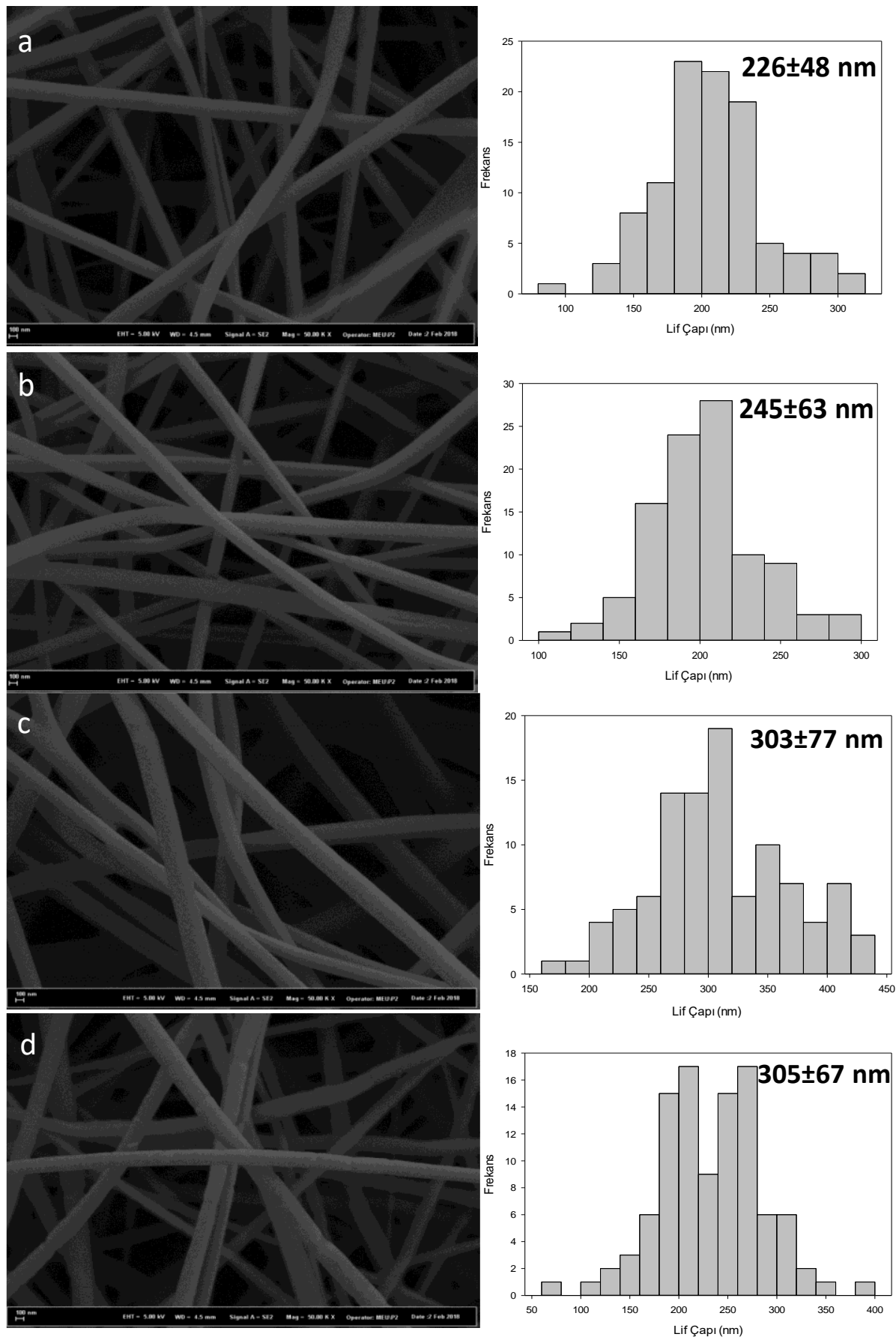

Şekil 4. Farklı zein çözeltilerinden elde edilen nanolifler ve kitin lifi içeren kompozit yapılarının FESEM görüntüleri a) saf zein, b) zein-NUY, c) zein-KL, d) zein-KL-NUY

Figure 4. FE-SEM images of nanofibers obtained from different zein solutions and their composite structures containing chitin fiber a) pure zein, b) zein-MEO, c) zein-CF, d) zein-CF-MEO 

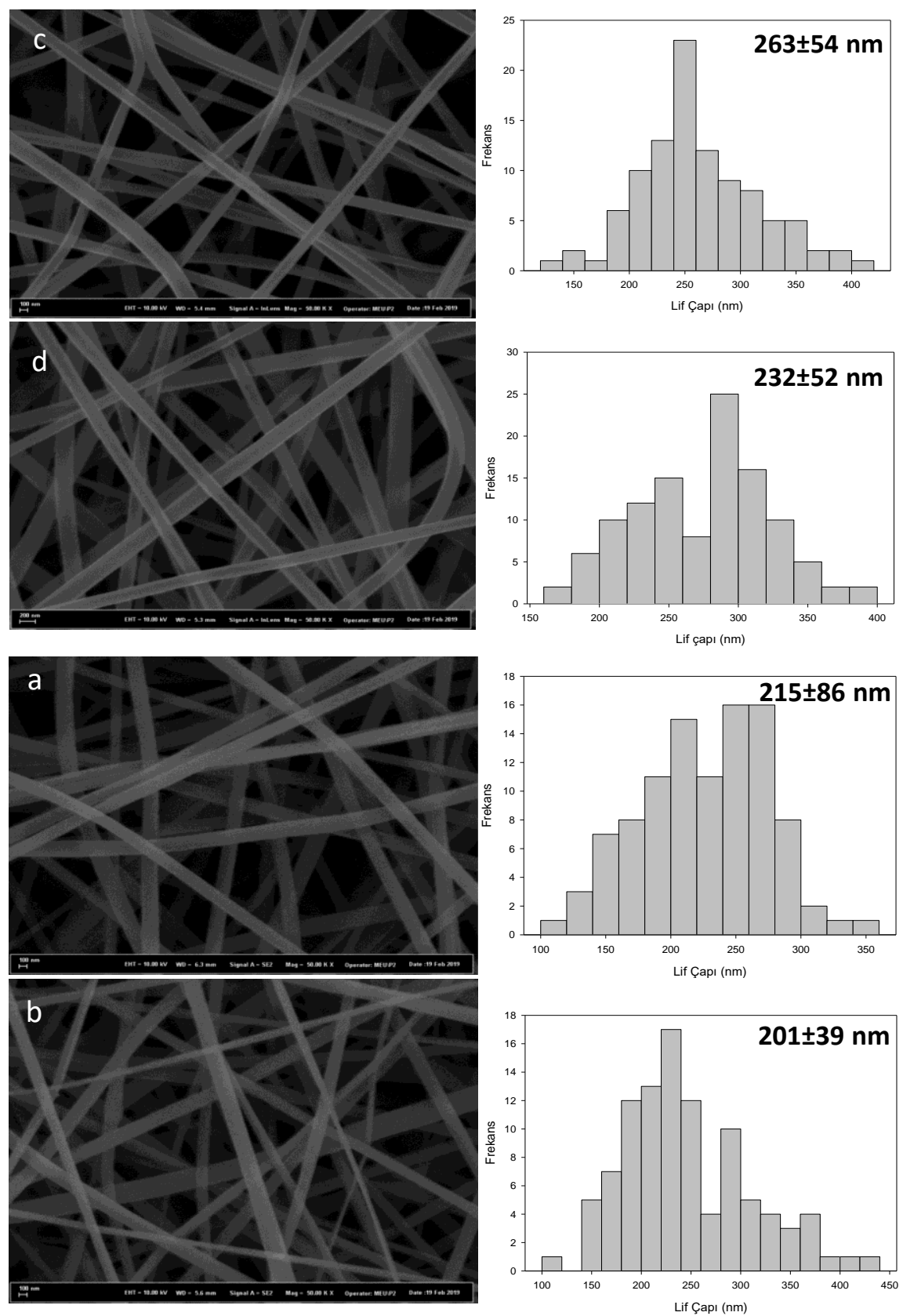

Şekil 5. Farklı zein çözeltilerinden elde edilen nanolifler ve kitin mikro kristalleri içeren kompozit yapılarının FE-SEM görüntüleri a) saf zein, b) zein-NUY, c) zein-KMK, d) zein-KMK-NUY

Figure 5. FE-SEM images of nanofibers obtained from different zein solutions and their composite structures containing chitin microcrystals a) pure zein, b) zein-MEO, c) zein-CM, d) zein-CM-MEO 


\section{Fourier Dönüşümlü Kızılötesi Spektrofotometre (FTIR)}

Zein, zein-NUY, zein-KMK ve zein-NUY-KMK liflerinin FTIR spektrumları Şekil 6'da verilmiştir. Saf zein çözeltisinden elde edilen lifin FTIR spektrumunda protein bantları için spesifik olan Amit A, Amit I ve Amit II pikleri, 3300, 1651 ve $1537 \mathrm{~cm}^{-1}$ de belirlenmiştir. Amit A piki N-H gerilme titreşim, Amit I piki $\mathrm{C}=\mathrm{O}$ gerilme, Amit II ise $\mathrm{N}-\mathrm{H}$ bükülme ve $\mathrm{C}-\mathrm{N}$ gerilme gruplarından meydana gelmektedir (Bancila vd., 2016). 2929 $\mathrm{cm}^{-1}$ 'de alifatik grup C-H gerilme titreşimi, 1447 $\mathrm{cm}^{-1}$ 'de ise $\mathrm{CH}_{2}$ gerilme titreşimi bulunmuştur. Zein içeren diğer nanobiyokompozit yapılarda da zeinin sahip olduğu spesifik piklere rastlanmıştır (Şekil 6b, 6c ve 6d). Nane uçucu yağı içeren nanobiyokompozit yapiların FTIR spektrumlar1 Şekil 6b ve 6d'de verilmiştir. Nane uçucu yağının $3349 \mathrm{~cm}^{-1}$ 'deki absorpsiyon piki, içerisinde bulunan hidroksil $(-\mathrm{OH})$ gruplarının gerilmesi nedeniyle oluşmaktadır. $\mathrm{Bu}$ pik nanobiyokompozit yapilarında zeinden kaynaklı $3300 \mathrm{~cm}^{-1}$ de oluşan pik ile birleşmektedir. C-H gerilme gruplarından dolayı meydana gelen 2927 $\mathrm{cm}^{-1}$ deki pik yap1s1, zeinin $2929 \mathrm{~cm}^{-1} \mathrm{de}$ oluşturduğu pik yapisı ile birlikte görüntülenmektedir. Nane uçucu yağındaki alken $(\mathrm{C}=\mathrm{C})$ yapisindan kaynaklanan $1633 \mathrm{~cm}^{-1} \mathrm{de}$ pikin, $1651 \mathrm{~cm}^{-1}$ deki zeinin Amit I pikiyle çakışarak keskinleştiği belirlenmiştir. $1537 \mathrm{~cm}^{-1} \mathrm{de}$ nane uçucu yağından dolayı meydana gelen $\mathrm{C}=\mathrm{C}$ gerilmesi, zeinin aynı noktada oluşturduğu Amit II pikiyle birleşmektedir. Nane uçucu yağının sahip olduğu aromatik halkalardan kaynaklanan piklerin nanobiyokompozit yapilarda $599 \mathrm{~cm}$ ${ }^{1}$ den $700 \mathrm{~cm}^{-1} \mathrm{e}$ kaydığı belirlenmiştir (Jain vd., 2016).

Kitin mikro kristallerinin FTIR spektrumu Şekil 6e'de gösterilmiştir. Kitinin Amit I $(\mathrm{C}=\mathrm{O})$ yapısı 1614 ve $1593 \mathrm{~cm}^{-1}$ de bölünmüş çift pikler şeklinde görülmüştür. N-H ve O-H gerilmeleri ise 3051 ve $2889 \mathrm{~cm}^{-1}$ 'de meydana gelmiştir. Amit II piki $1519 \mathrm{~cm}^{-1}$ 'de C-N-H germe titreşimi ve N-H bükme titreşimi kombinasyonu olarak görülmüştür. $\mathrm{Bu}$ sonuçlar literatürdeki kitin ile yapılan çalışmalar ile uyumludur. Liu ve diğerleri (2016) yaptıkları çalışmada kitindeki Amit I $(\mathrm{C}=\mathrm{O})$ pikini 1659 ve $1621 \mathrm{~cm}^{-1}$ 'de belirlemişlerdir. Amit II yapısını ise keskin bir pik şeklinde $1560 \mathrm{~cm}^{-1}$ de gözlemlemişlerdir. Kitin mikrokristallerinin pikleri, nanobiyokompozit yapısının sahip olduğu zein polimerinin piklerinin şiddetini artırmışır.

\section{Mekanik Özellikler}

Elde edilen nanobiyokompozit yapilı liflerin kalınlık, gerilme direnci ve uzama miktarı Çizelge 2'de gösterilmiştir. Nanobiyokompozit yapilı liflerin kalınlıkları $0.034 \pm 0.01$ ile $0.101 \pm 0.03 \mathrm{~mm}$ arasında değişim göstermiştir. Saf zeinden elde edilen liflerin gerilme direnci $1.16 \pm 0.24 \mathrm{MPa}$ ve uzama miktarı \%5.01 \pm 1.12 olarak belirlenmiştir. Zein çözeltisine nane uçucu yağı eklenmesiyle elde edilen liflerin gerilme direnci $1.44 \pm 0.36 \mathrm{MPa}$ ve uzama miktarı $\% 6.65 \pm 1.64$ olarak belirlenmiştir. Zein çözeltisine nane uçucu yağ1 ilave edilmesinin, nanobiyokompozit yapıll liflerin mekanik özelliklerini iyileştirdiği ve bu iyileştirmenin istatistiksel olarak anlamlı $(p<0.05)$ bulunan bir artşşa neden olduğu bulunmuştur. Yapılan bir çalışmada çay ağacı ve manuka uçucu yağlarının polilaktik asit bazlı elektroeğrilmiş liflerin mekanik ve antibakteriyel özellikleri üzerindeki etkisi araştırılmıştır. Kullanılan uçucu yağların uzama miktarı ve gerilme direncini 12 kata kadar arttığ1 sonucuna varılmıştır. Bu artışın nedeni uçucu yağ bileşiminde bulunan düşük molekül ağırlıklı bileşiklerin polimer zincirlerinin hareketliliğini ve polimer serbest hacmini artırarak plastikleştirici etki göstermesidir (Zhang vd., 2017).

Zein çözeltisine kitin liflerinin eklenmesi ile elde edilen nanoliflerin gerilme direnci $1.35 \pm 0.33 \mathrm{MPa}$ ve uzama miktarı $\% 9.52 \pm 1.14$ olarak belirlenmiştir. Kitin mikro kristallerinin eklenmesi ile elde edilen liflerin gerilme direnci $0.92 \pm 0.09$ $\mathrm{MPa}$ ve uzama miktarı \%6.33 \pm 0.56 olarak belirlenmiştir. Saf zeine kitin lifi ilavesinin, yapının gerilme direncini ve uzama miktarını artırdığı belirlenmiştir. Saf zeine kitin mikro kristali eklenmesi ise saf zeine göre gerilme direncini azaltırken, uzama miktarını artırmıştır. Bu değişim istatistiksel olarak anlamlı $(p>0.05)$ bulunmamıştır. Bu azalmanın nanolifli yüzeyler içerisinde sürekli bir faz oluşturan kitin liflerine 
karşın mikro kristallerin homojen olmayan aşırı birikimi ve topaklanma eğilimi ile ilişkili olduğu düşünülmektedir. Nanolifli yüzeylerin üretiminde kullanılan mikro kristal konsantrasyonunun optimize edilmesi ile mekanik özelliklerin geliştirilebileceği sonucuna varılmıştır. Benzer bir şekilde Yang ve arkadaşları (2019) tarafindan yapılan bir çalışmada elektroeğirme yöntemi kullanılarak polilaktik asit (PLA) ve polimer ağırlı̆̆1 üzerinden farklı oranlarda $(\% 0$, $\% 3, \% 5, \% 7, \% 10)$ selüloz nanolifleri (CNF) içeren nanokompozitler üretilmiştir. Elde edilen nanolifli membranların mekanik özellikleri incelenmiş ve selüloz liflerinin biyopolimer çözeltisine $\% 3$ oranında eklenmesi ile elde edilen nanoliflerin gerilme direncinin saf PLA'dan oluşan nanoliflere göre daha yüksek olduğu belirtilmiştir. Öte yandan daha yüksek konsantrasyonlarda gerilme direncinin azalmas1 selüloz liflerinin aşırı birikimine bağlı olarak topaklanma eğilimi göstermesine bağlanmıştır.

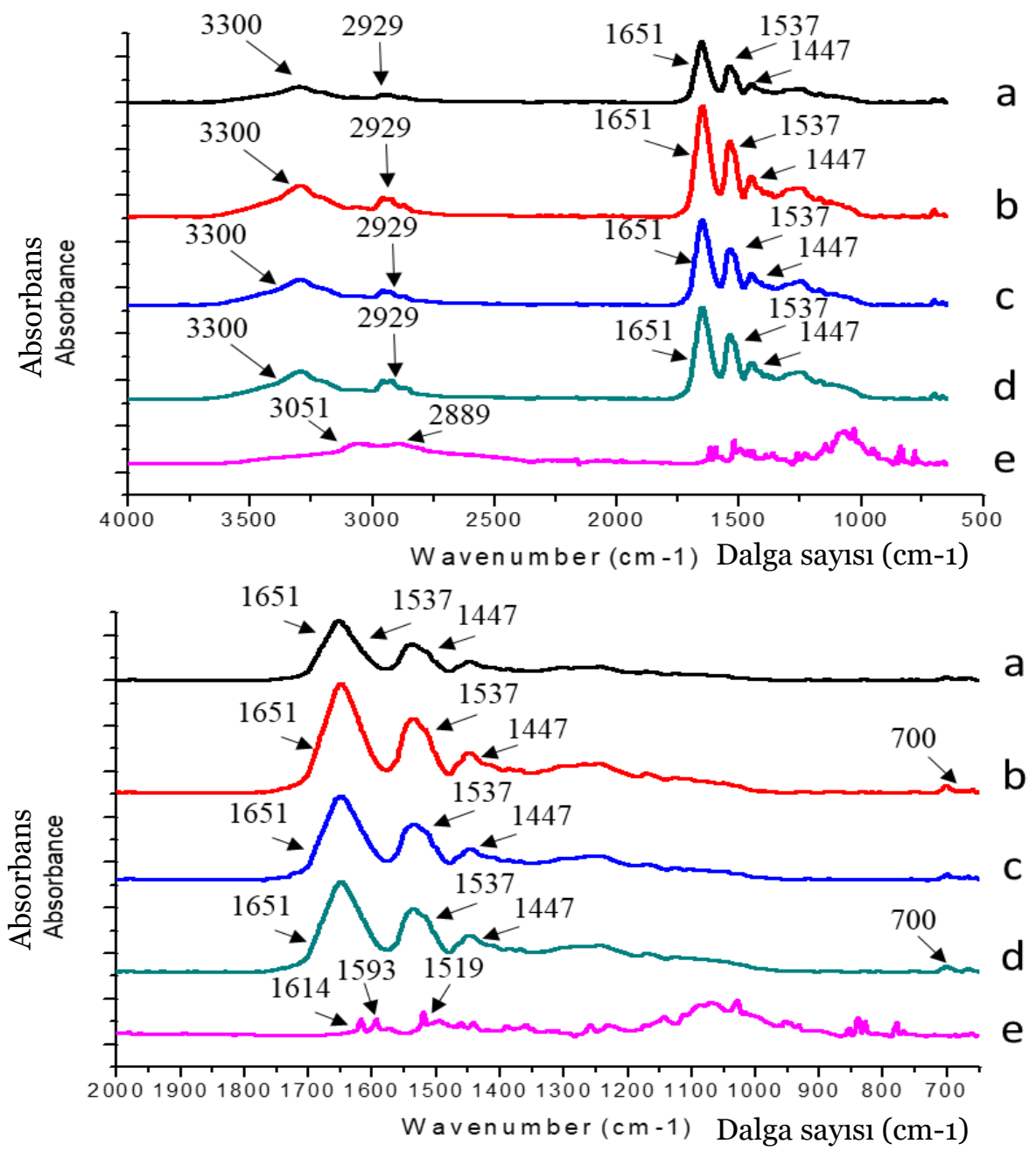

Şekil 6. Farklı zein çözeltilerinden elde edilen nanolifler ve kitin mikro kristalleri içeren kompozit yapıların FTIR spektrumları a) saf zein, b) zein-NUY, c) zein-KMK, d) zein-KMK-NUY, e) KMK Figure 6. FTIR spectrums of nanofibers obtained from different zein solutions and their composite structures containing chitin microcrystals a) pure zein, b) zein-MEO, c) zein-CM, d) zein-CM-MEO, e) CM 
Zein çözeltisine NUY ile birlikte kitin liflerinin eklenmesi ile elde edilen nanolifli yüzeylerin gerilme direnci $1.14 \pm 020 \mathrm{MPa}$ ve uzama miktarı $\% 7.11 \pm 0.21$ olarak belirlenmiştir. Zein çözeltisine NUY ile birlikte kitin mikro kristallerinin eklenmesi ile elde edilen nanoliflerin gerilme direnci ise $0.63 \pm 0.12 \mathrm{MPa}$ ve uzama miktar1 $\% 5.77 \pm 2.36$ olarak belirlenmiştir. Nane uçucu yağ1 ile birlikte kitin lifi ve kitin mikro kristali eklenmesi, elektroeğrilmiş membran yapıların gerilme direncini saf zeine göre azaltmışır. Gerilme direncindeki azalmanın nane uçucu yağına kitin mikro kristali eklendiğinde daha fazla olduğu belirlenmiştir. Elektroeğrilmiş membran yapılara NUY ile birlikte KL veya KMK eklenmesi, liflerin uzama miktarını saf zeine göre artırmış fakat bu değişim istatistiksel olarak anlamlı bulunmamıştır ( $p>0.05)$. Saf zeine NUY ile birlikte kitin liflerinin eklenmesi kitin mikro kristallerinin ilavesine göre uzama miktarını daha fazla artırmışır. Mekanik özellik açısından, nanobiyokompozit yapilara kitinin lif formunun ilave edilmesinin mikro kristal formunun ilave edilmesine göre daha etkili olduğu belirlenmiştir. $\mathrm{Bu}$ sonuçların, kitin mikro kristallerinin kitin liflerine göre daha yüksek sertlik ve kristalliğe sahip olması ve nanolifli yüzeylerde süreksiz bir faz oluşturmasina bağlı olduğu düşünülmektedir (Yang vd., 2019).

Çizelge 2. Farklı zein çözeltilerinden elde edilen nanolifler ve kitin lifi/kitin mikro kristalleri içeren kompozit yapılarının mekanik özellikleri

Table 2. Mechanical properties of nanofibers obtained from different zein solutions and their composite structures containing chitin fiber/chitin microcrystals

\begin{tabular}{lccc}
\hline $\begin{array}{l}\text { Deney } \\
\text { Run }\end{array}$ & $\begin{array}{c}\text { Kalınlı }(\mathrm{mm}) \\
\text { Thickness }(\mathrm{mm})\end{array}$ & $\begin{array}{c}\text { Gerilme direnci }(\mathrm{MPa}) \\
\text { Tensile strength }(\mathrm{MPa})\end{array}$ & $\begin{array}{c}\text { Uzama Miktar1 }(\%) \\
\text { Strain }(\%)\end{array}$ \\
\hline 1 & $0.034 \pm 0.01^{\mathrm{a}}$ & $1.16 \pm 0.24^{\mathrm{b}}$ & $5.01 \pm 1.12^{\mathrm{a}}$ \\
2 & $0.036 \pm 0.00^{\mathrm{a}}$ & $1.44 \pm 0.36^{\mathrm{c}}$ & $6.65 \pm 1.64^{\mathrm{a}}$ \\
3 & $0.043 \pm 0.00^{\mathrm{a}}$ & $1.35 \pm 0.33^{\mathrm{b}, \mathrm{c}}$ & $9.52 \pm 1.14^{\mathrm{b}}$ \\
4 & $0.067 \pm 0.01^{\mathrm{ab}}$ & $1.14 \pm 0.20^{\mathrm{b}}$ & $7.11 \pm 0.21^{\mathrm{a}, \mathrm{b}}$ \\
5 & $0.098 \pm 0.00^{\mathrm{bc}}$ & $0.92 \pm 0.09^{\mathrm{a}, \mathrm{b}}$ & $6.33 \pm 0.56^{\mathrm{a}}$ \\
6 & $0.101 \pm 0.03^{\mathrm{c}}$ & $0.63 \pm 0.12^{\mathrm{a}}$ & $5.77 \pm 2.36^{\mathrm{a}}$ \\
\hline
\end{tabular}

Farklı harfler istatistiksel olarak önemli farklılıkları göstermektedir $(p<0.05)$.

\section{Antimikrobiyal Aktivite}

Nane uçucu yağının ve kitin lifleri/kitin mikro kristalleri ile güçlendirilmiş zein/NUY içeren nanobiyokompozit liflerin antimikrobiyal aktivitesi iki test mikroorganizması E. coli (Gramnegatif) ve $S$. aureus (Gram-pozitif) kullanılarak Agar Disk Difüzyon yöntemi ile belirlenmiştir. Bunlar hayati tehdit oluşturan firsatç1 mikroorganizmalar oldukları için, patojenite, direnç, bulaşıcı süreç incelemesi için model olarak kullanılan mikroorganizmalardır (Bachir Raho ve Benali, 2012). Nane uçucu yağının antimikrobiyal etkisinin sonuçları Şekil 7'de gösterilmiştir. NUY $S$. aureus üzerinde $22.0 \pm 0.35 \mathrm{~mm}$, E. coli üzerinde ise $11.3 \pm 0.05 \mathrm{~mm}$ zon çap1 oluşturmuştur. E. coli mikroorganizmasının nane uçucu yağına toleransının daha yüksek olduğu, nane uçucu yağının S.aureus üzerinde daha etkili olduğu belirlenmiştir.

Kitin lifleri/kitin mikro kristalleri ve NUY içeren ve içermeyen liflerin antimikrobiyal etkileri karşılaştırılmıştır. Zein-NUY-KL içeren nanobiyokompozit yapıların çevresinde berrak zon oluşumu gözlenmemiştir (Şekil 8). Kitin mikro kristallerinden üretilen nanobiyokompozit yapılarda ise; kitin lifleri ile elde edilen nanobiyokompozit yapılara göre berrak zon çap1 oluşumu görülmüsstür (Şekil 9). Bu durum; kitinin morfolojisinin kristalleşmesiyle antimikrobiyal etkinin oluşmasını sağlayan nane uçucu yağının daha iyi enkapsüle edilmesinin sağlandığını ve antimikrobiyal özelliğe sahip nanobiyokompozit yapının elde edildiğini göstermiştir. Ortalama zon çapının değişimi Çizelge 3'de gösterilmiştir. Zein- 
NUY-KMK içeren nanobiyokompozitlerin $S$. aureus üzerinde oluşturduğu zon çap1 $14.5 \mathrm{~mm}$ iken, E. coli üzerinde oluşturduğu zon çap 13.03 mm'dir. Nanobiyokompozit yapiların antimikrobiyal özelliğinin, nane uçucu yağında olduğu gibi, S.aureus üzerinde daha etkili olduğu tespit edilmiştir (E. coli< S.aureus).

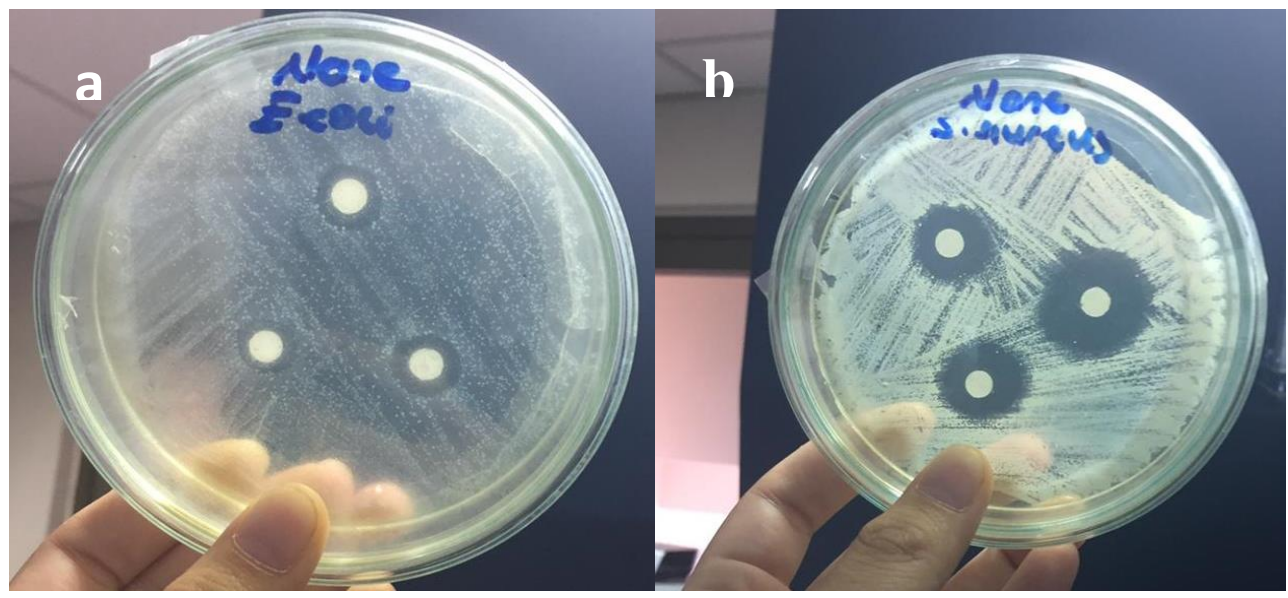

Şekil 7. Nane uçucu yağının (NUY) test mikroorganizmaları üzerindeki antimikrobiyal aktivitesi a) E.coli, b) S. aureus

Figure 7. Antimicrobial activity of mint essential oil (MEO) on test microorganisms a) E. coli, b) S. aureus
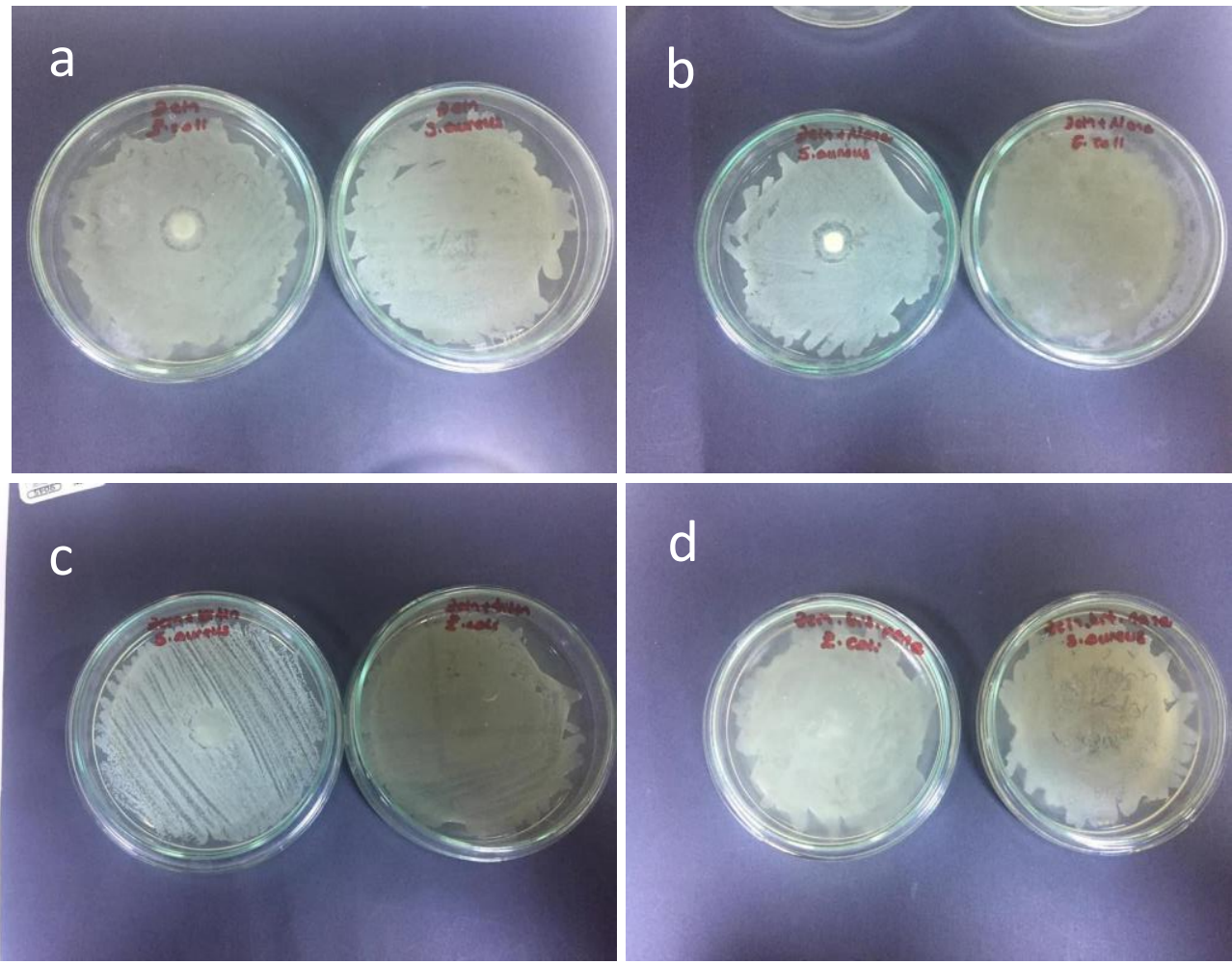

Şekil 8. Farklı zein çözeltilerinden elde edilen nanolifler ve kitin lifi içeren kompozit yapılarının disk difüzyon testleri a) saf zein, b) zein-NUY, c) zein-KL, d) zein-KL-NUY

Figure 8. Disk diffusion tests of nanofibers obtained from different zein solutions and their composite structures containing chitin fiber a) pure zein, b) zein-MEO, c) zein-CF, d) zein-CF-MEO 

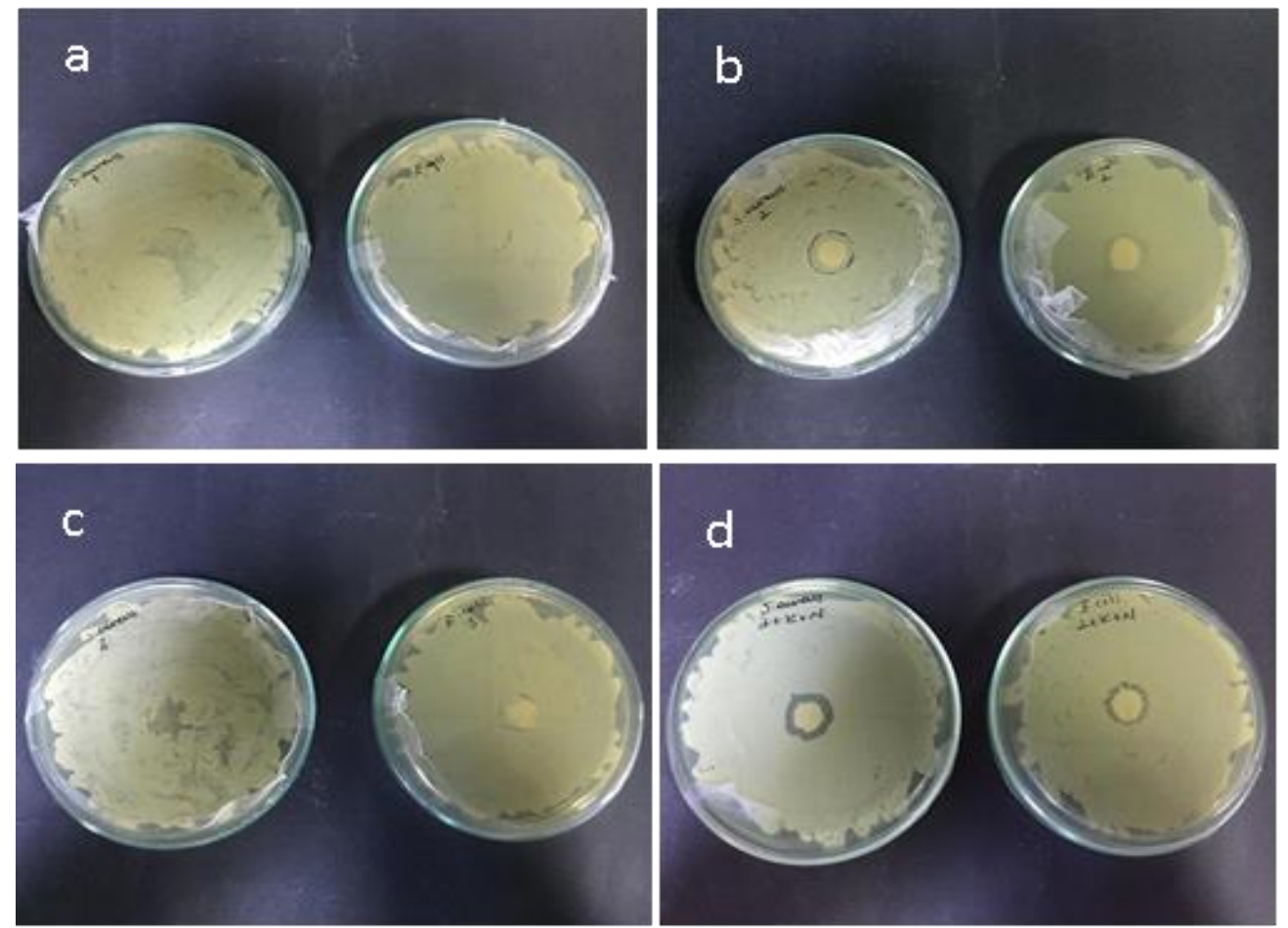

Şekil 9. Farklı zein çözeltilerinden elde edilen nanolifler ve kitin mikro kristalleri içeren kompozit yapılarının disk difüzyon testleri a) saf zein, b) zein-NUY, c) zein-KMK, d) zein-KMK-NUY

Figure 9. Disk diffusion tests of nanofibers obtained from different zein solutions and their composite structures containing chitin microcrystals a) pure zein, b) zein-MEO, c) zein-CM, d) zein-CM-MEO

Liakos ve diğerleri (2017) çalışmalarında esansiyel yă içeren malzemelerin mikrobiyal bağlanma ve canlı oluşumu engellediğini belirtmişlerdir. Aynı grubun bir başka çalışmasında limon yağının selüloz asetat içerinde enkapsüle edilmesiyle elde edilen nanopartiküllerin $S$. aureus mikroorganizmasi üzerinde antimikrobiyal etkisi olduğu belirlenmiştir (Liakos vd., 2016). Literatürdeki bir diğer çalışmada sodyum aljinat ile enkapsüle edilen esansiyal yağın Candida albicans mantarı üzerinde etkisinin E. coli'ye göre daha fazla olduğu ve film içerisindeki yă̆ miktarının artmasıyla oluşan zon çapinın doğru orantılı olduğu belirlenmiştir (Liakos vd., 2014).

Yapilan bu çalışma sonucunda elektroeğirme yöntemi kullanılarak nane uçucu yağı yüklü, kitin lifleri ve kitin mikro kristalleri ile güçlendirilmiş nanoliflerin morfolojileri, mekanik ve antimikrobiyal özellikleri belirlenmiştir. Nanoliflerin nane uçucu yağı sayesinde antimikrobiyal özellik kazandığ1 görülmüştür. Kitin lifleri ve kitin mikro kristallerinin ilave edilmesinin nanoliflerin mekanik özelliklerini iyileştirdiği tespit edilmiştir. $\mathrm{Bu}$ sonuçlar, elde edilen nanobiyokompozit yapiların potansiyel aktif ambalaj sistemlerinde yenilikçi bir çözüm olabileceğini göstermektedir.

Çizelge 3. Farklı zein çözeltilerinden elde edilen nanolifler ve kitin lifi/kitin mikro kristalleri içeren kompozit yapılarının antimikrobiyal aktiviteleri

Table 3. Antimicrobial activities of nanofibers obtained from different zein solutions and their composite structures containing chitin fiber/chitin microcrystals

\begin{tabular}{lcc}
\hline & \multicolumn{2}{c}{ Zon çap1 $(\mathrm{mm})$} \\
& \multicolumn{2}{c}{ Zone diameter $(\mathrm{mm})$} \\
\hline Deney & S. aureus & E.coli \\
Run & S. aureus & E.coli \\
\hline 1 & 0 & 0 \\
2 & 0 & 0 \\
3 & 0 & 0 \\
4 & 0 & 0 \\
5 & 0 & 0 \\
6 & $14.50 \pm 0.01$ & $13.03 \pm 0.01$ \\
\hline
\end{tabular}




\section{TEŞEKKÜR}

$\mathrm{Bu}$ çalışma, Mersin Üniversitesi Bilimsel Araştırma Projeleri Birimince (BAP), 2018-1TP2-2738 nolu proje ile desteklenmiştir. Çalışma kapsamında kullanılan nane uçucu yağını temin eden Çakıroğlu Yağ (Çakıroğlu Uçucu Yağ San. Tic. Ltd. Şti., Mersin) firmasına ve mavi yengeç kabuklarını temin eden Mezitli Balık Pazarı'na teşekkür ederiz.

\section{KAYNAKLAR}

Antunes, M.D., da Silva Dannenberg, G., Fiorentini, Â.M., Pinto, V.Z., Lim, L.T., da Rosa Zavareze, E., Dias, A.R.G. (2017). Antimicrobial electrospun ultrafine fibers from zein containing eucalyptus essential oil/cyclodextrin inclusion complex. Int J Bio Macromolecules 104:874-882.

Bachir Raho, G., Benali, M. (2012). Antibacterial activity of the essential oils from the leaves of Eucalyptus globulus against Escherichia coli and Staphylococcus aureus. Asian Pac J Trop Biomed 2(9):739-742.

Bancila, S., Ciobanu, C-I., Murariu, M., Drochioiu, G. (2016). Ultrasound-assisted zein extraction and determination in some patented maize flours. Rev Roum Chim 61(10):725-731.

Barrosa, A., Moraisa, S.M., Ferreiraa, P.A.T., Vieirab, I.G.P., Craveiroc, A.A., Fontenelled, R., Jane Menezesa, E., Silvaa, F., Sousa, H. (2015). Chemical composition and functional properties of essential oils from Mentha species. Ind Crops Prod 76:557-564.

Dong, Z., Wu, Y., Wang, Q., Xie, C., Ren, Y., Clark, R. L. (2012). Reinforcement of electrospun membranes using nanoscale $\mathrm{Al}_{2} \mathrm{O}_{3}$ whiskers for improved tissue scaffolds. J Biomed Mater Res 100(4):903-910.

Jain, P.K., Soni, A., Jain, P., Bhawsar, J. (2016). Phytochemical analysis of Mentha spicata plant extract using UV-VIS, FTIR and GC/MS technique. J Chem Pharm Res 8(2):1-6.

Jin, X. Y., He, C. W., Liu, X. R., Yan, X. J., Yu, Q. Z. (2017). Effect of cellulose crystal content on the mechanical property of nano-crystal line cellulose/lignin composite fibrous film. Key Eng Mater 727:527-531.
Junkasem, J., Rujiravanit, R., Supaphol, P. (2006). Fabrication of $a$-chitin whisker-reinforced poly(vinylalcohol) nanocomposite nanofibres by electrospinning. Nanotechnol 17:4519-4528.

Kara, H., Xiao, H., Sarker, M., Jin, T., Sousa, A., Liu, C., Tomasulu, P.M. (2016). Antibacterial poly(lactic acid) (PLA) film grafted with electrospun PLA/allyl isothiocyanete fibers for food packacing. J Appl Polym Sci 10:1-8.

Liakos, I., Abdellatif, M., Innocenti, C., Scarpellini, A., Carzino, R., Brunetti, V., Marras, S., Brescia, R., Drago, F., Pompa, P. (2016). Antimicrobial lemongrass essential oil-copper ferrite cellulose acetate nanocapsules. Molecules 21:520, doi:10.3390/molecules21040520.

Liakos, I., Holban, A., Carzino, R., Lauciello, S., Grumezescu, A. (2017). Electrospun fiber pads of cellulose acetate and essential oils with antimicrobial activity. Nanomater 7:84, doi:10.3390/nano7040084.

Liakos, I., Rizzello, L., Scurr, D., Pompa, P., Bayer, I., Athanassiou, A. (2014). All-natural composite wound dressing films of essential oils encapsulated in sodium alginate with antimicrobial properties. Int J Pharm 463:137-145, doi:10.1016/j.ijpharm.2013.10.046.

Liu, H., Liu, W., Luo, B., Wen, W., Liu, M., Wang, X. (2016). Electrospun composite nanofiber membrane of poly(l-lactide) and surface grafted chitin whiskers: Fabrication, mechanical properties and cytocompatibility. Carbohydr Polym 147:216-225.

Mincea, M., Negrulescu, A., Ostafe, V. (2012). Preparation, modification and applications of chitin nanowhiskers: A Rev Adv Mater Sci 30:225242.

Nostro, A., Germano, M.P., D’angelo, V., Marino, A., Cannatelli, M.A. (2000). Extraction methods and bioautography for evaluation of medicinal plant antimicrobialactivity. Lett Appl Microbiol 30(5):79-84.

Paillet, M., Dufresne, A. (2001). Chitin whisker reinforced thermoplastic nanocomposites. Macromolecules 34:6527-6530. 
Pereira de Abreu, D. A., J. M. Cruz, P. P. Losada. (2012). Active and intelligent packaging for the food industry. Food Rev Int 28:146-187.

Realini, E.C., Marcos, B. (2014). Active and intelligent packaging systems for a modern society. Meat Sci 98:404-419.

Sartoratto, A., Machado, A.L.M., Delarmelina, C., Figueria, G.M., Duarte, M.C.T., Rehder, V.L.G. (2004). Composition and antimicrobial activity of essential oils from aromatic plantsused in Brazil. Brazilian J Microbiol 35(4):275-280.

Schmatz, D., Costa, J., Greque de Morais, M. (2019). A novel nanocomposite for food packaging developed by electrospinning and electrospraying. Food Packaging Shelf Life 20100314.

Tang, Y., Zhou, Y., Lan, X., Huang, D., Luo, T., Ji, J., Wang, W. (2019). Electrospun gelatin nanofibers encapsulated with peppermint and chamomile essential oils as potential edible packaging. J Agric Food Chem 67(8):2227-2234.

Tiryakioğlu, B. (2004). Euphorbia seguieriana bitkisinden hazırlanan özütlerin antibakteriyel etkilerinin incelenmesi, Çanakkale Onsekiz Mart Üniversitesi Fen Bilimleri Enstitüsü, Yüksek Lisans Tezi, Çanakkale, Türkiye.

Torres-Giner, S. (2011). Chapter 5:Electrospun nanofibers for food packaging applications. Multifunctional Nanoreinforced Polym Food Packaging, Woodhead Publishing Limited, 108-125, doi.org/10.1533/9780857092786.1.108.

Vermeiren, L., Devlieghere, F., Beest, V.M., Kruijf, N., Debevere, J. (1999). Developments in the active packaging of foods. Trends Food Sci Technol 10(3):77-86.
Wen, P., Zhu, D., Feng, K., Liu, F., Lou, W., Li, N., Zong, M., Wu, H. (2016). Fabrication of electrospun polylactic acid nanofilm incorporating cinnamon essential oil/ $\beta$ cyclodextrin inclusion complex for antimicrobial packaging. Food Chem 196:996-1004.

Wen, Q., Lan, W., Zhang, R., Whang, S., Liu, Y. (2017). Development of poly(lactic acid)/chitosan fibers loaded with essentialoil for antimicrobial applications. Nanomaterials 7: 194207.

Yang, Z., Li, X., Si, J., Cui, Z., Peng, K. (2019). Morphological, mechanical and thermal properties of poly(lactic acid)(PLA)/cellulose nanofibrils(CNF) composites nanofiber for tissue engineering.J Wuban Univ Technol Mater Sci Ed 34(1):207-215.

Zeng, J.B., He, Y., Li, S., Wang, Y. (2012). Chitin whiskers: an overview. Biomacromolecules 13:1-11.

Zhang, L., Yongshang, L., Weng, L. (2004). Morphology and properties of soy protein isolate thermoplastics reinforced with chitin whiskers. Biomacromolecules 5:1046-1051.

Zhang, W., Huang, C., Kusmartseva, O., Thomas, N.L., Mele, E. (2017). Electrospinning of polylactic acid fibres containing tea tree and manuka oil. Reactive Functional Polym 117:106-111.

Zivanovic, S., Li, J., Davidson, P.M., Ki, K. (2007). Physical, mechanical, and antibacterial properties of chitosan/PEO blend films. Biomacromolecules 47:1505-1510. 